\title{
VPLYV JACQUA COPEAUA NA METODIKU HERECKEJ PRÍPRAVY MICHELA SAINT-DENISA: OD PRAXE ŠKOLY ÉCOLE DU VIEUX-COLOMBIER PO SÚBOR COMPAGNIE DES QUINZE
}

\author{
CECILIA CARPONI \\ Sapienza - Università di Roma, Taliansko
}

\begin{abstract}
Abstrakt: Prenos hereckého tréningu z pôvodnej školy do iných škôl je zložitou teatrologickou témou. Herecké školenia Michela Saint-Denisa, historikmi divadla málo reflektované, sú pre túto tému exemplárnou ukážkou, a to z dvoch hlavných dôvodov. Po prvé, synovec, študent a dedič Jacqua Copeaua bol prvým, kto premenil herecké skúšky z École Vieux-Colombier a z praxe skupiny Copiaus na ucelenú metódu. Po druhé, preniesol Copeauove školenie do anglicky hovoriaceho divadelného sveta. Táto štúdia sa zameriava na prvý inštitucionálny kontext, vytvorený Saint-Denisom, ktorý bol prototypom jeho pedagogiky. London Theatre Studio bolo založené v roku 1935 a ostalo aktívne až do vypuknutia druhej svetovej vojny. Štúdia skúma prechod od úplne experimentálnej praxe (t. j. výskum, ktorý uskutočnil Copeau so svojimi žiakmi) k vypracovanej metóde. Tento systém bol koncipovaný kvôli prenosu, a preto bol štandardizovaný. Ukazuje sa, že Saint-Denis bol správcom Copeauovho odkazu, zodpovedným za prenos výsledkov práce experimentálnych dielní do štruktúrovanej metódy a za jej d’alší rozvoj v iných hereckých školských programoch. Navyše týmto presunom z Francúzska do Anglicka naštepil Saint-Denis britské divadelné prostredie a stal sa spojovacím článkom medzi dvoma rôznymi divadelnými kultúrami. ${ }^{1}$
\end{abstract}

Klúčové slová: divadlo, herec, tréning, herecký program, maska, improvizácia, mím

Je známe, že Michel Saint-Denis (1897 - 1971) venoval vel'kú čast' svojej kariéry a svojho života - príprave hercov. ${ }^{2}$ Jeho kniha Training for the Theatre (Príprava pre divadlo) ${ }^{3}$, do ktorej vložil viacero článkov a prednášok prezentovaných na konci pät'-

\footnotetext{
${ }^{1}$ Rada by som sa pod'akovala svojim učitel’om Guidovi Di Palmovi a Marcovi Consolinimu, ktorí trpezlivo dohliadali na môj výskum, aj pani Rosine Gautier (manželke syna Michela Saint-Denisa), pánovi Baptistovi Marreymu (asistentovi Saint-Denisa v Štrasburgu) a jeho manželke Alix Romer (bývalej študentke na École supérieure d'art dramatique), ktorí sa so mnou podelili o t’ažko získatel'né spomienky a dokumenty.

${ }^{2}$ Počas svojej dlhej kariéry Saint-Denis organizoval vyučovanie a prípravu hercov vychádzajúce zo systematickej metódy, čo bolo súčastou študijných programov herectva najmä v období medzi tridsiatymi a šest’desiatymi rokmi minulého storočia vo viacerých inštitúciách, napr. v London Theatre Studio (1936 1939) a Old Vic Theatre School (1947 - 1952) v Londýne, v l'École Supérieure d'Art Dramatique (od roku 1953 dodnes) v Štrasburgu, National Theatre School of Canada (od roku 1960 doteraz) v Montreale, Stratford Studio (1962 - 1967) v Stratford-upon-Avone a v Drama Division (od roku 1968 doteraz) na Juilliard School v New Yorku.

${ }^{3}$ SAINT-DENIS, M. Training for the Theatre. Premises \& Promises, Ed. S. Magito. New York - London : Theatre Arts Books-Heinemann Educational Books LTD., 1982. Kniha, ktorú editovala Suria Magito, manželka Saint-Denisa, bola publikovaná 12 rokov po jeho smrti. Magitovej obdiv k divadelníkovi prináša uhol pohladu, ktorý sa neusiluje iba o zachovanie Saint-Denisovho odkazu, ale aj o jeho preverovanie. Na pomedzí biografie a úsilia dat čitatelom k dispozícii príručku na prípravu hercov, je výsledný text nekompatibilný so Saint-Denisovým dielom. Stačí azda iba spomenút', že v úvode Suria Magito tvrdí, že ked' sa Saint-Denis prestahoval do Anglicka, „neexistovali žiadne doktríny resp. dopredu stanovené metódy, ktoré
} 
desiatych a začiatku šest’desiatych rokov minulého storočia, je zhrnutím jeho pedagogickej praxe, akýmsi sprievodcom pre študentov a zbierkou poučení z jeho života. Saint-Denis v príručke prikladá najväčší význam experimentálnej práci s maskami a improvizácii s postavami: „Bolo to v roku 1924, ked” mi po prvýkrát napadlo, že pri príprave hercov môžem využívat' improvizáciu na budovanie postáv a docielenie komického efektu, či už s maskami alebo bez nich" ${ }^{\text {, }}$, spomína v najdôležitejšej kapitole knihy. Fráza „napadlo mi“ evokuje svojráznu metodológiu, ktorá vyzerá dost” nespol’ahlivo, ked’že (možno nevedome, možno zámerne) neberie do úvahy fakt, že proces učenia a tvorby je podstatnou častou vývinu Saint-Denisovej metódy hereckej prípravy. Odkial' však pochádza ten spomínaný „,nápad“, tá myšlienka, ktorá sa stala základom Saint-Denisovej pedagogickej praxe? Kde sa dá nájst’ zdroj metódy, ktorú zaviedol na účely prípravy hercov v tridsiatych až šest’desiatych rokoch - metódy, ktorá sa pri príprave nových generácií študentov herectva používa dodnes?

\section{Práca v Théâtre du Vieux-Colombier (1920 - 1924)}

Korene Saint-Denisovej divadelnej identity treba hl'adat' v Théâtre du Vieux-Colombier. ${ }^{5}$ Už ako dvadsiatnik, v rokoch 1919 - 1920, sa stal asistentom a administratívnym tajomníkom svojho strýka Jacqua Copeaua. Prevádzkové úlohy, ktoré Saint-Denis plnil v rámci súboru, sa rýchlo rozrástli. Navyše začal onedlho aj inscenovat divadelné hry, po odchode Louisa Jouveta a Charla Dullina sa zúčastňoval skúšok $\mathrm{v}$ úlohe asistenta réžie a inšpicienta.

Na svoje začiatky v úlohe Copeauovej pravej ruky spomína takto: „Dostal som sa k nemu v roku 1920 a nasledujúce štyri roky som všetok čas trávil v Théâtre du Vieux-Colombier. (...) Niekedy som v inscenáciách aj účinkoval a pravidelne som navštevoval Copeauovu školu, aby som videl, ako sa pripravujú malé skupiny hercov v mojom veku. Zaujali ma cvičenia, ktoré pritom robili a ktoré boli svojou povahou značne experimentálne." ${ }^{\prime 6}$

Napriek tomu, že organizačné a administratívne povinnosti bránili Saint-Denisovi usilovne študovat’ a navštevovat' École du Vieux-Colombier, kam sa zapísal v novembri 1921, mohol sa zúčastnit’ aspoň niektorých seminárov a sledovat prácu študentov. Túto skutočnost’ dokazujú poznámky Marie-Madeleine Gautier, ktorá uvádza, že Saint-Denis bol vo viacerých cvičeniach vel'mi aktívny.?

\footnotetext{
by aplikoval.“ (s. 11). Takéto tvrdenie neberie do úvahy vplyv Jacqua Copeaua na Saint-Denisov prístup k vyučovaniu hercov.

${ }^{4}$ Tamže, s. 177.

${ }^{5}$ Narodil sa 13. 9. 1897 v Beauvais matke Marguerite Copeau (Jacquova sestra) a Charlovi Saint-Denisovi. Michel odišiel zo svojho rodného mesta, ked' mal sedem rokov, prestahoval sa so svojou matkou a mladšou sestrou do Paríža. Marguerite bola rada, že môže odíst’ od manžela pre jeho problémy s pitím a gamblerstvom. So žiadostou o pomoc sa obrátila na Copeaua. Saint-Denis vo svojom strýkovi od počiatku videl náhradu za chýbajúceho otca a ked' bol tínedžer, bral ho ako referenčný bod. Copeau o synovca prejavoval záujem, poskytoval mu stabilitu a stal sa pre neho vzorom, inšpiráciou, ale aj autoritou. Pozri Autobiographie de Michel Saint-Denis, 1905 - 1929. In Fond Michel Saint-Denis, BNF, 4-COL-83/1(2).

${ }^{6}$ SAINT-DENIS, M. Training for the Theatre, s. $25-26$.

${ }^{7}$ GAUTIER, M. École du Vieux-Colombier. Notes de cours prises par Marie-Madeleine Gautier. In Fond Michel Saint-Denis, BNF, 4-COL-83/291.
} 
Saint-Denis viackrát preukázal hlboké vedomosti nielen o študijnom programe školy ${ }^{8}$, ale aj zámer zreformovat’ v nej vyučovanie dramatického umenia. Počas seminára o Copeauovom divadelnom odkaze na jar roku 1959 označil Saint-Denis školu za „miesto, kde dochádza k znovuobjavovaniu divadla“9. Od študentov sa vyžadovala prísna disciplína s ciel'om pomôct' im objavit’ jednotlivé formy dramatického výrazu: „Copeau svojich mladých študentov považoval za talentované deti, s ktorými skúšal objavovat tajomstvá herectva a experimentovat's novými alebo obnovenými formami dramatického výrazu, a to bez vplyvu ,normálnych' hercov v jeho súbore. " ${ }^{10}$ Saint-Denis, ktorý podobne ako Copeau chcel, aby sa herec stal tvorivým umelcom a nie iba vykonávatel'om, trval na dôležitosti improvizačných techník. Ich cielom malo byt' vykorenenie manierov "šmíry“ v mladých hereckých talentoch: „Išlo o to, aby herec tvoril, aby sa ponoril hlboko do seba, do priestoru, v ktorom sa môže vymanit’ z neprirodzeného herectva. " ${ }^{11}$ A tak Copeau vo svojej škole začal študovat fyzické výrazy hercov, jeho vyučovacími prostriedkami sa stali tanec, pantomíma, improvizácia a práca s maskami.

V interview z marca 1933 Saint-Denis spomína výsledky práce s tzv. základnými maskami ${ }^{12}$, ktorú v škole vykonával: „Výsledky sa dostavili okamžite: hanbliví žiaci sa rýchlo oslobodili pri gestikulácii a vd’aka dôrazu na výraz boli nútení používat' celé telo a hned’ si našli vlastný štýl. "13 Maska sa stáva konštitučným prvkom pri príprave hercov, nástrojom na zosilnenie telesného výrazu a jeho ovládania zo strany študenta, ale aj prostriedkom na odstránenie zábran pri skúšaní a vystupovaní na javisku: „Cvičenie s maskami sa hned' od začiatku stalo našou pracovnou metódou. " 14

Existuje príhoda, ktorú Saint-Denis často rozprával a ktorá nám umožní pochopit proces pedagogického výskumu realizovaného v École du Vieux-Colombier. Copeau zadal úlohu pozostávajúcu z improvizovaného cvičenia pantomímy 19-ročnému dievčatu, ktoré sa však vel’mi trápilo: „Nedokázala to urobit - bola príliš plachá a hanblivá - až napokon [Copeau] vytiahol z nohavíc vreckovku a povedal jej: ,Daj si tú vreckovku na tvár a skús urobit' s ňou pantomímu.' A tak nanovo objavili masku (...). Masky aj sami vyrábali - nie však estetické masky alebo masky imitujúce čínsku resp. inú tradíciu, jednoducho masky l’udských tvárí. Niekedy to boli masky ich vlastných tvárí alebo jednej tváre a sledovali ich účinok na vývoj telesného výrazu. ${ }^{\text {15 }}$

\footnotetext{
${ }^{8}$ Pozri napr. SAINT-DENIS, M. Formation du jeune acteur. In Le Théâtre dans le monde, 1954, roč. 4, č. 1, s. $37-49$.

${ }^{9}$ SAINT-DENIS, M. The Theatrical contribution of Jacques Copeau. Neformálna prezentácia Michela Saint-Denisa na Divadelnom seminári, jar 1959. Fond Michel Saint-Denis, BNF, 4-COL-83/41.

${ }^{10}$ SAINT-DENIS, M. Theatre: the Rediscovery of Style, New York: Theatre Arts Books, 1960. 2. vydanie: Theatre: the Rediscovery of Style and other Writings. Ed. J. Baldwin. New York : Routledge Theatre Classics, 2009 , s. 45.

${ }^{11}$ SAINT-DENIS, M. The Theatrical contribution of Jacques Copeau.

${ }^{12}$ Saint-Denis rozlišuje medzi základnou maskou a maskou-postavou. Pozri SAINT-DENIS, M. Training for the Theatre, s. 169 - 181.

${ }^{13}$ M. Saint-Denis v rozhovore s M. H. Bergerom v denníku Excelsior, 19. 3. 1933.

${ }^{14}$ Tamže.

${ }^{15}$ SAINT-DENIS, M. The Theatrical contribution of Jacques Copeau. Tú istú príhodu uvádza Saint-Denis v knihe Training for the Theatre, s. 169 - 170: „Využívanie masiek pri príprave hercov má svoj pôvod v udalosti, ktorá sa stala pred mnohými rokmi počas skúšky v divadle Vieux-Colombier, ked’ mladá herečka zdržala skúšanie, pretože nedokázala prekonat’ svoju plachost’ a vyjadrit’ emócie svojej postavy náležitou fyzickou aktivitou. Režisér Jacques Copeau nechcel čakat’ a zdržiavat’ ostatných, a tak jej na tvár dal vreckovku a vyzval ju, aby výstup zopakovala takto. Rýchlo sa uvol'nila a dokázala telom vyjadrit’ to, čo sa od nej očaká-
} 
Vreckovka na tvári sa stala liekom na hanblivost’, nepokoj, napätie, rozpaky či zábrany, ktoré bolo treba odstránit’ v prípade problémov neskúsených hercov $\mathrm{s}$ telesným výrazom. Práca s maskou fungovala ako ozajstný pedagogický nástroj, ktorý pomáhal oslobodit’ a zvýraznit’ fyzický výraz hercov.

\section{Súbor Copiaus v Burgundsku (1924 - 1929)}

Bol to práve súbor Copiaus, ktorý Saint-Denisovi umožnil kontakt s Copeauovou pedagogickou a didaktickou praxou: „Stal som sa riadnym členom súboru, s ktorým sme experimentovali na rôznych úrovniach, až sme neskôr začali pridávat’ komické improvizácie, resp. improvizácie s postavami, a to s maskami aj bez nich. "16 Saint-Denis sa učil pantomímu, improvizáciu, tvorbu masiek-postáv a ich využitie v inscenovaných menších dramatických tvaroch. Takisto študoval písanie dramatických textov a kolektívnu tvorbu. Každodenná príprava v skupine Copiaus bola zameraná na zostavenie divadelného súboru zloženého z plnohodnotne vyškolených hercov: „,Vstávali sme o siedmej ráno a vonku, na čerstvom vzduchu, sme začínali rozcvičkou. Pre Copeaua bolo dôležité, aby sme mali dobre nastavený svalový tonus, pretože svieže a agilné telo nám pomáhalo vyjadrovat’ vnútorné pocity. Pracovali sme s rytmom a tancom, učili sme sa rétoriku a skúmali sme pantomimické možnosti využívania masiek." ${ }^{17}$

Táto vytrvalá práca rýchlo priniesla ovocie: Saint-Denis si v krátkom čase vybudoval potrebnú umeleckú zručnost'. Práca s maskami prestala byt’ v tomto štádiu výhradne pedagogickou činnostou a spolu s improvizačnými technikami sa stala nástrojom tvorby, výrazu a dramaturgie. Nie je náhoda, že to bol práve Saint-Denis, kto stál pri zrode prvej masky-postavy, ktorú súbor Copiaus predstavil verejnosti. ${ }^{18}$ Postava sa volala Jean Bourguignon a išlo o pestrofarebný typ vychádzajúci z tradície postáv vinárov.

V Pernand-Vergelesses sa komediálna improvizácia a improvizácia postáv ešte zintenzívnila a skupina Copiaus svoj výskum rozšírila o klúčový koncept novej komédie, tzv. comédie nouvelle. Vidiecke prostredie, v ktorom sa súbor pohyboval, nevyhnutnost' spolužitia a práca vo vinohrade mali vplyv na skupinové improvizácie a z nich vyplývajúce dramaturgické podnety.

Saint-Denis napísal prvú verziu prológu k dielu Jean Bourguignon et les Copiaus (Jano Burgundský a Copiaus) 8. apríla $1925^{19}$ a 15. augusta diváci v Burgundsku pri sledovaní predstavenia Prologue de Meursault (Prológ v Meursaulte) i nasledujúceho Discours de Jean Bourguignon au public (Príhovor Jana Burgundského publiku) dali najavo svoje uznanie postave Jeana Bourguignona. ${ }^{20} \mathrm{~V}$ texte prológu sa Bourguignon

\footnotetext{
valo. Táto situácia sa stala inšpiráciou pre d’alšie hl’adanie možností používania masiek v procese prípravy hercov. Zistili sme, že ked’ je hercova tvár zakrytá maskou, ten l’ahšie stráca zábrany a dokáže íst’ aj za svoje bežné limity. Napriek tomu, že takýto prístup na jednej strane zosilnil fyzický výraz, zároveň herca naučil hospodárit’ s gestom a povzbudil ho v úsilí komunikovat aj bez slov. Bolo to určite vel'mi cenné zistenie."

${ }^{16}$ SAINT-DENIS, M. Training for the Theatre, s. 26.

${ }^{17}$ M. Saint-Denis v interview s M. H. Bergerom v denníku Excelsior, 19. 3. 1933.

${ }^{18}$ V roku 1925 začal na maskách-postavách pracovat’ Auguste Boverio. Postava sa mala volat’ Bidouille alebo Bicouille, avšak nikdy sa neobjavila na javisku.

${ }^{19}$ BING, S. Le journal de bord des Copiaus 1924 - 1929. Ed. D. Gontard. Paris : Editions Segher, 1974, s. 72. Prológ mal premiéru 17. 5. 1925.

${ }^{20}$ Tamže, s. $84-85$.
} 
predstavuje ako postava harlekýnovského typu - je pohotový a bystrý, pritom však neuvážlivý a náchylný na zosmiešňovanie. ${ }^{21}$ Je jedným z l’udu, typický burgundský vinár, ktorý predstiera, že je spojovníkom medzi skupinou Copiaus a obyvatelmi Meursaultu. Funkciou prológu bolo predstavit’ súbor divákom. Mužskí herci sa prezentujú ako členovia súboru Copiaus, ale herečky sa vydávajú za miestne dievčatá, ktoré sú zvedavé a zaujímajú sa o hercov. Boverio ukončí prológ týmito vetami: „Dámy a páni, naše predstavenie uvádzame po prvýkrát na javisku. Robíme to pre vaše potešenie. Naším jediným ciel’om je zabaviť vás. Budeme vás zabávat’ najlepšie ako vieme. Po predstavení bude na vás, aby ste nám povedali, či sme uspeli a či budete chciet', aby sme prišli znova. Ale teraz už pod’me na to..." ${ }^{22}$

$\mathrm{V}$ tejto chvíli Jean Bourguignon divákom povie, že je škoda, že neboli na skúškach jednotlivých frašiek, ktoré dnes večer uvidia. Konkrétne ide o tituly Le médecin malgré lui (Lekárom proti svojej vôli) a Arlequin Magicien (Kúzelník Harlekýn). Saint-Denis, hrajúc svoju postavu, žmurká na divákov a smeje sa, aby zosmiešnil riaditel'a súboru, Copeaua, ktorý je večne nespokojný. Počut’ tak hlas istej nevôle, ktorá sa začína šírit’ medzi členmi súboru Copiaus: „Ak by ste ich videli pri práci, asi by ste umreli od smiechu. Herec príde do skúšobne, vyzlečie sa a nechá si sotva spodnú bielizeň, aby zachoval aspoň posledný kúsok slušnosti. Potom vyhl'adá pána Copeaua aj s jeho nosiskom. Copeau stále chodí hore-dolu a komanduje: „Musí to byt' takto a takto!' Potom povie: „Musí mat’ špicaté brucho a úzky pás.' A tak tam začnú pre toho chudáka vymýšlat všetky tie nezmysly. Vatu prilepia sem aj tam. Môže byt'? Nie, nemôže, brucho je bud' príliš nízko, alebo príliš vysoko, prípadne je otočené nesprávnym smerom. Ked’ sa pre brucho konečne nájde správne miesto, odrazu je priúzka hrud'. A na hrud' ide hned' viac vaty! A všetko sa upevňuje pripináčikmi. Ten chudák musí stát bez pohybu, pokým Copeau okolo neho bzučí a lieta ako mucha, približuje a vzd’al'uje sa, aby výsledok svojej práce posúdil z odstupu. Ach! To je nápad! Musia pri tom byt trpezliví a dávat' pozor. A všetko musia robit's radostou. “23

Kým bola tvorba masiek-postáv v prvotnom štádiu, každodenný život sa prelínal s fantáziou a využíval sa pre potreby dramaturgie. Ako uvidíme neskôr, išlo o charakteristickú črtu vzniku celého radu pevných typov postáv, ktoré súbor Copiaus vytvoril.

V rokoch 1925 a 1926 si Copiaus získali divákov v celom regióne Côte d'Or. ${ }^{24}$ Po tom, čo si Copeau po svojom pracovnom nasadení v Burgundsku vzal volno, vrátil sa, aby skontroloval prípravu študentov a podporil ich zameranie na moderné, fixované typy tvorby. A tak práca v žánri comédie nouvelle pokračovala: masky, ktoré sa z obyčajných pomôcok zmenili na širšie koncipované nástroje telesného výrazu, sa stali hlavným a okamžite rozpoznatel’ným prvkom vytvárania fixných typov hercami. Saint-Denis a Jean Dasté vytvorili Oscara Kniea a Césara ${ }^{25}$, dve dobre vykreslené

\footnotetext{
${ }^{21}$ SAINT-DENIS, M. Prologue de Meursault. In Fond Michel Saint-Denis, BNF, 4-COLL-83/601.

${ }^{22}$ SAINT-DENIS, M. Textes des prologues. In Fond Michel Saint-Denis, BNF, 4-COL-83/601.

${ }^{23}$ Tamže.

${ }^{24}$ K repertoáru súboru Copiaus pozri BING, S. Le journal de bord des Copiaus; tiež GOURMEL, J.-B. Michel Saint-Denis. Un homme de Théâtre (1897 - 1971). [dizertačná práca]. Paris : Université Paris I Panthéon Sorbonne, 2005, s. $93-98$.

${ }^{25} \mathrm{Aj}$ iní členovia súboru vytvárali masky-postavy: Jean Villard vytvoril Gillesa, Auguste Boverio Bitouilla a Leon Chancerel strýka Sebastiena. Pozri DI PALMA, G. La nozione esatta di quella porzione di
} 
masky-postavy, ktoré sa mali stat’ dôležitou súčastou kolektívnych diel súboru Copiaus.

Jeden exemplár nepublikovaného scenára sa nachádza vo Fonde Michela Saint-Denisa vo Francúzskej národnej knižnici (BNF) v Paríži. Vd’aka nemu môžeme skúmat’ a pochopit’ jednotlivé fázy Saint-Denisovho tvorivého procesu. Ide zrejme o prepis improvizačného cvičenia zameraného na prehĺbenie charakterizácie postáv, alebo o tzv. canovaccio - scenár, ktorý sa mal neskôr d’alej rozpísat. Je rukopisom Saint-Denisa a má názov Histoire de Knie (Knieova história). Knie i César sa v ňom ocitajú v situáciách, v ktorých sa naplno prejavia ich rozdielnosti.

„(Scenár) Zvieratá:

1. Knie sa predstaví - povie, že má stretnutie s Césarom v záhrade Jardin des Plantes. César však mešká. Pokým Knie čaká, rozpráva sa s det’mi, ktoré tam stretne, o živote v Paríži, o škole, o kráse kontaktu so zvieratami.

2. Prichádza César a začína sa hádka o mieste stretnutia - malo to byt’ pred uškatcami alebo aligátormi, či vari pred Buffonovou sochou?

Potom sa však upokoja. Spojí ich kontakt s det’mi - pod Knieovým vedením. César s det’mi prehodí len zopár slov - vyzve ich, aby sa s ním išli pozriet na zvieratá; práve totiž dorazili obzvlášt divoké zvery. Knie sa bojí rovnako ako deti - najradšej by sa pozeral na divoké zvieratá v kine, alebo sa išiel pozriet’ na ovce. César vezme Kniea a deti - v záchvate hrdinstva - zvieratá dobre pozná a ide za nimi do klietky. Skupinku nevinných detí vyzve, aby išli s ním. Knie je proti, ale, bohužial', musí Césara nasledovat'.

Vojde tiger.

Vojde lev.

Vojde medved'.

Vojde opica.

Vojde krava.

Sú obklúčení. Zvieratá postupne okolo nich zužujú kruh. Knie sa odovzdá smrti, no César vydrží. Knie volá deti na pomoc - zvieratá sa však na nich medzitým už vrhli.

Zaznie hudba. Zvieratá sa upokoja - hýbu sa - a odchádzajú. César jemne spieva - César uteká z miestnosti.

S hudbou prichádzajú aj strážcovia.

Strážcovia vysvetlia, že zvieratá ušli a že vedia, ako ich privolat’ spät tancom. Rozprávajú sa s Knieom, ktorý práve prišiel z miesta, kde bola krava.

Končí zábava a žartovanie.“26

Pri analýze štruktúry textu je zrejmé, že vyrovnaný komediálny tím Césara a Oscara Kniea je modernou verziou Dona Quijota a Sancha Panzu. Na jednej strane César prahne po dobrodružstvách, ale bez zmyslu pre realitu, a na druhej strane stojí Oscar, ktorý je síce zbabelec, ale realista. Charakterizácia jednej postavy je silnejšia

fallimento che c'è in ogni opera. In Biblioteca Teatrale, 2012, BT 104, s. 36; MISTRÍK, M. Les Copiaus sans Copeau. In MISTRÍK, M. (ed.). Jacques Copeau hier et aujourd'hui, Bratislava - Paríž : VEDA, Les Editions de l'Amandier, 2014, s. 104.

${ }^{26}$ SAINT-DENIS, M. Histoire de Knie. In Fond Michel Saint-Denis, BNF, 4-COL-83/17. 
vd’aka porovnaniu s druhou postavou, a to nielen dramaturgicky, ale aj počas jednotlivých okamihov tvorivého procesu, ako základná fáza tvorby.

V knihe Training for the Theatre Saint-Denis podrobne rekonštruuje tvorivý proces, ktorý viedol k zrodu postavy Oscara Kniea, a aplikuje ho na študentov ako neoddelitel'nú súčast' svojej pedagogiky. Popis v príslušnom odseku je uvedený zoznamom rekvizít, s ktorými Saint-Denis začínal. Inými slovami, začínalo sa vždy tými prvkami použitými v predchádzajúcom predstavení, ktoré sa mohli stat’ nástrojmi rozširujúcimi funkčnost’ herca: „Väčšinou som začínal kostýmom. O Oscarovi som mal dlho vel’mi nejasnú predstavu, nič som nedokázal vytvorit', kým som nenašiel medzi kostýmami starý kabát z 19. storočia z Copeauovej adaptácie Bratov Karamazovovcov a plesnivé, čierno-zelené nafúkané nohavice, ktoré boli také poddajné, že menili tvar pri každom pohybe. Mal som poruke aj palicu a našiel som kus starého koberca, ktorý v zrolovanom tvare dodával taký pocit autority, aký by som nikdy nedosiahol iba gestikuláciou. Rekvizita nie je len rekvizitou, ako palica nie je iba palicou, istým spôsobom sa stáva doplnkom herca a poskytuje nekonečné možnosti premien. Tieto štyri predmety - kabát, nohavice, koberec a palica - naštartovali moju fantáziu a pomohli mi intuitívne vytvorit prvú verziu Oscara. Nedialo sa to však na intelektuálnej úrovni - nedostal som ,nápad' ako by mal Oscar vyzerat', skôr som to akoby cítil v kostiach. “27

Siluetu Oscara Kniea, vytvorenú na základe kontaktu so štyrmi scénickými predmetmi, dopíňa pozorovanie konkrétnych ludí, s ktorými mal Saint-Denis príležitost’ spolupracovat' - pozorovanie postáv z verejnej sféry, z jeho života, či z literárneho sveta: „Základ kostýmu ma priviedol k tomu, že som začal pozorne sledovat pohyb a gestá istej vtedajšej známej politickej osobnosti vo Francúzsku, ktorá nosila oblečenie podobného strihu. V malom švajčiarskom mestečku La Chaux-de-Fonds som so zaujatím sledoval nočného nosiča batožiny v hoteli, kde sme bývali - bol malý a mal vel'mi svojský spôsob chôdze, státia i rozprávania. Takéto skúsenosti mi postupne pomáhali vytvorit’ postavu Oscara. K nim sa pridali aj spomienky na môjho otca a ovplyvnili ma tiež viaceré literárne diela, napr. Dostojevského a Dickensa - alebo to boli postavy starého pána Karamazova či Pickwicka? Už ani neviem. Každopádne som postupne získaval predstavu masky pre túto postavu a nakoniec som ju aj sám navrhol. Inšpirácia prišla z pocitu zo šiat na mojom tele, z pozorovania toho politika a nosiča a potom zo samotnej masky. ${ }^{28}$

V procese tvorby postavy je obrazotvornost’ vyživovaná skutočnými udalostami - životy hercov sa miešajú s fantáziou. Podobne ako Saint-Denis čerpá zo spomienok na svojho otca pri rozpracovaní postavy Oscara Kniea, Dasté si pri prezentovaní Césarovho života spomína na chvíle zo svojho života a mladosti. Napríklad uvádza blízke stretnutie s pastierkou, vel'mi podobnou jednej z postáv, ktorú hrala Marie-Hélène Copeau, Dastého nastávajúca manželka, počas dramatických cvičení na École du Vieux-Colombier. ${ }^{29}$

\footnotetext{
${ }^{27}$ SAINT-DENIS, M. Training for the Theatre, s. 177 - 178.

${ }^{28}$ Tamže.

${ }^{29}$ Césarov životopis a dramatické cvičenia, v ktorých Maïène hrá pastierku, sú uchované vo Fonde Jacqua Copeaua. Životopis je súčastou nepublikovaného textu zo zakladača z roku 1925 (J. Dasté, L'École du Vieux-Colombier, notes de Jean Dasté, boîte 3, dossier 12), a cvičenie pochádza z textu La Gardeuse des chèvres endormie, boîte 3, dossier 4. Pozri DI PALMA, G. La nozione esatta di quella porzione di fallimento che c'è in ogni opera, s. 37, pozn. č. 45.
} 
Saint-Denis sa vždy usiloval podporovat’ fyzické výrazivo svojich postáv. Ked si dal Oscar Knie na hlavu klobúk, bol pripravený na akciu. Aby však Knie mohol byt' kompletný, Saint-Denis si predstavil praktické situácie, ako je napríklad pasáž prepísaná v citovanom texte z Histoire de Knie. ${ }^{30}$ Improvizácia sa začína takto: Ako Knie rozpráva? Ako komunikuje s inými? Čo má rád? Čo nenávidí? Ako reaguje na vonkajší svet?

„Oscar sa vlastne ešte nenarodil, pretože zrod postavy je vel’mi pomalý proces. Existovalo iba akési embryo, silueta postavy. Oscar mal t’ažkosti pri rozprávaní, pretože $\mathrm{v}$ tomto počiatočnom štádiu bola jeho existencia založená predovšetkým na fyzických výrazoch. Dlho iba mrmlal, až do chvíle, ked’ sa jeho silueta začala vypíňat. Nechcel som nič konkretizovat príliš skoro. Potom som Oscara zaradil do jednoduchých scenárov - bežných, každodenných situácií. Prvýkrát sa napríklad stretol s Césarom. Úplnou náhodou Dasté prišiel do rovnakej fázy svojej práce s Césarom, ktorý bol zatial' iba akousi suchou rybou, istým typom postavy Dona Quijota. Môj Oscar sa mal stał Sanchom Panzom, ale s ovel’a väčšou dávkou zdravého rozumu a slobody v prejave. Oscar Césara nenávidel. Prostredníctvom skíc, ktoré sme s Dastém urobili, som v mojej postave objavil jednu malú, ale dôležitú osobnú črtu. Musel som byt vel'mi opatrný, aby som tento prvý konkrétny záblesk charakteru postavy nestratil. Neskôr sa objavila d’alšia črta, ktorá vystúpila do popredia a výrazne pomohla ostatným, spontánnejšie pôsobiacim Oscarovým fyzickým výrazom. Potom sa k tejto črte pridali d’alšie a d’alšie. Zakaždým som tieto vlastnosti vyskúšal v akcii a v zvláštnych situáciách - hl'adal som také, ktoré by sedeli do charakteru rýchlo sa vyvíjajúcej postavy Oscara Kniea. “31

Stretnutie Kniea s Césarom tak pomohlo Saint-Denisovi a Dastému v priamom vzájomnom konflikte objavit nové aspekty oboch postáv. Na konci tohto zdĺhavého a zložitého tvorivého procesu sa Oscar Knie vyznačoval týmito hlavnými charakterovými črtami: „Po celej sérii pokusov a omylov - improvizácii, skúšaní po sebe nasledujúcich výstupov a ich inscenovaní bezo zmien (okrem úprav menších detailov a intenzity) - sa konečne zrodil Oscar Knie. Bol naivný, márnivý, sentimentálny, slabý (avšak panovačný, ked’ sa mu darilo), náchylný k extrémom, lahko sa rozhneval, bol zúfalý, často opitý. Ako postava vel’a rozprával, bol energický a niekedy dokonca obscénny. “32

Oscar Knie sa nakoniec stal plnohodnotnou maskou-postavou, ktorá bola hotová a pripravená íst' na javisko a pomôct’ prebudit’ obrazotvornost' divadelníkov. Stal sa jednotkou, samostatnou bunkou. Bol kompletný ako postava, ale potreboval príbeh. V liste neznámeho dátumu, ktorý Dasté zrejme napísal niekedy v roku 1926, Knie na javisku existuje ako začiatok niečoho nového: „,(..) Nemôžem sa dočkat', ked’ budeme spolupracovat', určite dokážeme niečo nové. Niektoré Knieove maniery a slová sa zapísali do mojej pamäte ako chorál, ako začiatok niečoho nového. " 33 Bola to primárna ingrediencia a základný stavebný prvok comédie nouvelle, použitel’ný pre všetky d’alšie ciele a zámery.

\footnotetext{
${ }^{30}$ SAINT-DENIS, M. Histoire de Knie.

${ }^{31}$ SAINT-DENIS, M. Training for the Theatre, s. $178-179$.

32 Tamže, s. 179.

${ }^{33}$ List Jeana Dastého Michelovi Saint-Denisovi, (1926?). In Fond Michel Saint-Denis, BNF, 4-COL-83/161.
} 
Absencia autora v súbore Copiaus však spôsobila, že sa spoliehali na Copeaua, ktorý mal na starosti výber vyhovujúcich hier. Od roku 1926 sa tak súbor začína venovat produkciám, ktoré vznikali metódou kolektívnej tvorby. Jedným z najväčších úspechov bola inscenácia La Danse de la ville et des champs (Tanec mesta a polí), ktorú napísal Michel Saint-Denis a hudbu zložil Jean Villard. ${ }^{34}$ Práve v uvedenej inscenácii debutujú Saint-Denisove masky-postavy - táto produkcia je to niečo, čoho začiatkom bol Knie. Predstavenie využíva prvky tanca, akrobacie, spevu, pantomímy, grammelotu, masiek a improvizácií. Saint-Denis hrá Oscara Kniea a predstavenie uvádza prológom, v ktorom Jean Bourguignon predstavuje súbor: „Ja som šéf! Vediem súbor Copiaus, ktorý tu dnes vystupuje. Je to súbor najvyššieho rádu - a to hovorím so všetkou skromnostou. Ponúka pohl’ad na najrozličnejšie l’udské typológie (...). “35 Toto predstavenie zožalo obrovský úspech a takmer všetky kritiky boli pozitívne.

Nasledujúci rok súbor Copiaus inscenuje druhú kolektívne vytvorenú inscenáciu s názvom Les Jeunes gens et l'araignée ou La Tragédie imaginaire (Mládež a pavúk alebo Zdanlivá tragédia), ktorú opät’ napísali Saint-Denis a Villard. ${ }^{36}$ Hlavnými postavami sú Knie a César. Ide o jednoduchý príbeh a zápletku, do ktorej však vložili dvadsat'minútový výstup čistej pantomímy, ktorý divákov tak zaujal, že predstavenie prekonalo aj úspech titulu La Danse de la ville et des champs. Kritiky boli pozitívne. Ćlánok publikovaný v časopise Comœdia sa sústredil na masku-postavu Oscara Kniea, ktorú porovnával s fixovanými typmi postáv commedie dell'arte. ${ }^{37}$

Popri umeleckej práci Saint-Denis v Burgundsku nad’alej plnil svoje administratívne povinnosti. V novembri 1927, ked' Copeau odcestoval na sériu prednášok do New Yorku, Saint-Denis prevzal vedenie súboru. ${ }^{38} \mathrm{~S}$ rozšírenou zodpovednostou si uvedomoval potrebu umeleckej nezávislosti od Copeaua, ktorý vtedy prežíval silnú duchovnú krízu a prezentoval vel'mi rozporuplné zámery. Chcel sa oslobodit’ od bremena zodpovednosti za súbor, avšak nad’alej považoval členov skupiny Copiaus za sebe podriadených študentov. Spomal'oval tak proces odstraňovania princípu poslušnosti a pritom redukoval svoju zaangažovanost́. Výsledkom bolo, že nielen Saint-Denis, ale všetci členovia súboru pocitovali rastúcu potrebu autonómnosti.

Jednou z najväčších prekážok pre súbor Copiaus bol chýbajúci dramatik - autor, ktorý by poznal hercov a mohol s nimi spolupracovat'. Ako Saint-Denis napísal v knihe Training for the Theatre, súbor sa vyznačoval vel'kou mierou kreativity a imaginácie, aj výraznými technickými zručnostami. Avšak ak sa mala comédie nouvelle úspešne presadit', potrebovali dramatika, ktorý by dokázal naplno využit ich kapacity: „Presne ako sme predpokladali, po všetkých rokoch strávených s Copeauom sme sa stali súborom $\mathrm{s}$ bohatou fantáziou a skvelými technickými prostriedkami, ktoré nám umožňovali v našich dielach prezentovat mnohé aspekty a charakteristiky sveta

${ }^{34}$ Inscenácia mala premiéru 4. 3. 1928 v Meursault, po nej nasledovalo turné s minimálne 16 predstaveniami. Pozri La Danse de la ville et des champs. Presse, Calendrier. Fond Michel Saint-Denis, BNF, 4-COL$83 / 355(3)$.

${ }^{35}$ SAINT-DENIS, M. - VILLARD, J. La Danse de la ville et des champs. Fond Michel Saint-Denis, BNF, 4-COL-83/355(1).

${ }^{36}$ Predstavenie malo premiéru 27. 4. 1929 v Beaune. Pozri Les Jeunes gens et l'araignée ou La Tragédie imaginaire. Fond Michel Saint-Denis, BNF, 4-COL-83/362. Text bol neskôr publikovaný in MISTRÍK, M. (ed.). Jacques Copeau hier et aujourd'hui, s. $259-378$.

${ }^{37}$ VINCENT, V. „Les Jeunes Gens et l'Araignée“ ou „La Tragédie imaginaire“. In Comædia, 12. 5. 1929.

${ }^{38}$ BING, S. Le journal de bord des Copiaus 1924 - 1929, s. 128. 
okolo nás. Čo nám však chýbalo, bolo určite viac hercov, ale predovšetkým autor-dramatik. Copeau vedel, že základnou podmienkou pre úspech inscenácií, ktoré by otvorili novú dimenziu divadelnej práce, bolo zohnat správneho autora, ideálne akúsi reinkarnáciu Aischyla alebo Shakespeara, či niekoho ako Lorca. ${ }^{\text {39 }}$

\section{Compagnie des Quinze (1930 - 1935)}

Po rozpustení skupiny Copiaus v roku 1929 sa Saint-Denis pokúšal o spojenie členov burgundského súboru založením Compagnie des Quinze - telesa, v ktorom potom pracoval ako producent a umelecký riaditel' v rokoch 1930 - 1935. Konečne sa tvorivo oslobodil od Copeauovho vplyvu, ktorý bol často obmedzujúci a deštruktívny. V období uvedených piatich rokov Saint-Denis v novom súbore dosiahol prvé úspechy ako umelecký riaditel', tzv. chef de troupe, ale hlavne ako herecký pedagóg.

Saint-Denis svoj prvý súbor, v ktorom bol oficiálne producentom aj umeleckým šéfom, nazval „jedným z priamych umeleckých potomkov tvorivého ducha Jacqua Copeaua“" ${ }^{\text {, }}$ ale aj „následníkom burgundskej skupiny Les Copiaux [sic] posilnenej o d’alších hercov" "41. A skutočne, po zlyhaní experimentu v Burgundsku sa Compagnie des Quinze skladala iba z menšej skupiny bývalých členov súboru Copiaus - pribudlo niekol'ko študentov herectva, ktorí boli noví v Copeauovom okruhu. Hoci tieto veci boli tvorivým oslobodením pre Saint-Denisa a jeho kolegov, ukázalo sa, že bude problém obnovit’ pracovné metódy, ktoré vytvorili v Pernande. Ani sám Saint-Denis, ani d’alší bývalí členovia súboru Copiaus sa nedokázali vzdat’ tvorivej atmosféry, na ktorú si zvykli počas burgundského obdobia, takisto však nechceli podlahnút tlaku komerčných centrálnych divadiel v Paríži.

V procese vytvárania umeleckého programu, ktorý mal určit podstatu Compagnie des Quinze, Saint-Denis identifikoval tieto kl'účové faktory: prítomnost’ dramatika, ktorý bude spolupracovat' so súborom a prispievat' do procesu produkcie pôvodných hier; opätovné angažovanie hercov, ktorí sa pripravovali, študovali a pracovali v École du Vieux-Colombier, resp. neskôr v Burgundsku; výber nových hercov-študentov, ktorí budú vyškolení tak, ako by boli u Copeaua; a nakoniec partnerstvo s divadelnými remeselníkmi, scénografmi a skladatelmi. ${ }^{42}$

Vzdelávací proces, ktorý Saint-Denis a jeho súbor aplikovali na prípravu hercov-študentov prijatých s ciel'om posilnit’ súbor Quinze, sa vracia k pedagogickej praxi, ktorú umelci využívali v Burgundsku. Základným princípom je improvizácia „s maskami i bez nich“43. Jeden zo Saint-Denisových študentov Pierre Alder, známy pod umeleckým menom Pierre Rischmann, vo svojich pamätiach Les temps de la Compagnie des Quinze, nevydanom, na stroji písanom, cca 130-stranovom dokumente, ktorý sa v súčasnosti nachádza vo Fonde Michela Saint-Denisa, uvádza poučnú historku týkajúcu sa prístupu k práci s improvizáciou a maskami. Predtým ako Saint-Denis prijal Aldera ako herca a študenta, pozval ho do štúdia Ville d'Avray, kde preskúšal

\footnotetext{
${ }^{39}$ SAINT-DENIS, M. Training for the Theatre, s. 27.

${ }^{40}$ Tamže, s. 33.

${ }^{41}$ Tamže.

${ }^{42}$ SAINT-DENIS, M. Actes de la Société d'exploitation théâtrale. In Fond Michel Saint-Denis, BNF, 4-COL-83/371.

${ }^{43}$ SAINT-DENIS, M. Mes années au Vieux Colombier. In Europe: revue littéraire mensuelle, 1962, č. 396 397, apríl - máj, s. $62-70$.
} 
jeho tvorivé schopnosti a talent pre improvizáciu: „Povedal mi, aby som si ju [masku] pozorne prezrel. Bola to hlava baculatého muža, jemná a naivná, azda aj trochu detinská. Saint-Denis mi povedal: ,Tú masku použi iba vtedy, ked’ cítiš, že tebou preniká všetko to, čo pre teba znamená. Uchop ju oboma rukami a nasad' si ju na hlavu ako čiapku. Chvílu počkaj a potom si ju stiahni na tvár. Od tej chvíle tvoje prejavy už viac nie sú výrazom teba. Hovor, čo chceš, či skôr, čo chce hovorił tvoja postava. Za seba môžeš hovorił až vtedy, ked’ si dáš masku z tváre dolu. “" 44

Jean Dasté v interview, ktoré s ním urobil Saint-Denis, spomína na cvičenia s maskami v École du Vieux-Colombier, pretože tam aplikovali vel'mi podobnú metódu. Alder aj Dasté spomínajú stav, ktorý predchádzal použitiu masky. Išlo o proces vnímavého pozorovania masky predtým, ako si ju herec nasadil, proces tichého premýšlania a čakania. $\mathrm{V}$ oboch prípadoch ide o postoj, ktorý demonštruje obrovský rešpekt voči tomuto divadelnému nástroju: „Skôr ako sme začali, naučili sme sa mat úctu k maske - naučili nás, aby sme nevstupovali do nej tak, ako by sme za bežných okolností vstupovali do niečoho iného. Najdôležitejšie bolo, aby sme sa úplne zbavili predstavy o karnevalových maskách (...). Potom sme mohli prejavit’ rešpekt voči maske ako nástroju, čo nám umožnilo nielen si ju nasadit', ale predovšetkým prijat’ príslušnú emóciu. “45

Saint-Denis vyzval Aldera, aby mal masku na tvári iba vtedy, ked’ cíti, že ním prechádza jej emócia. Dasté si v podobnom duchu spomína na to, že študenti École du Vieux-Colombier mali dovolené začat’ uvedené cvičenie len vtedy, ak boli „dostatočne presiaknutí esenciou danej masky, ako aj vnútornou a vonkajšou dispozíciou nevyhnutnou na jej použitie“. ${ }^{46}$ Tento prístup k používaniu masiek, formalizovaný Saint-Denisom v École des Quinze, je tak priamym pokračovaním praxe, ktorá bola rozvinutá pod Copeauovým vedením v experimentálnom období na škole Théâtre du Vieux-Colombier a neskôr v Burgundsku.

Škola Théâtre du Vieux-Colombier bola prostredím, v ktorom sa naplno rozvinula Saint-Denisova divadelná identita, ako aj Copeauova pedagogická metóda, čo si všimol už mladý Saint-Denis v roku 1921. Zároveň radikálne ovplyvnila prípravu hercov a položila základy tradície divadelnej pedagogiky.

V Saint-Denisovej metóde prípravy hercov bol hlavný dôraz položený na improvizáciu a prácu s maskami - tie boli nielen nástrojmi na zosilnenie fyzického výrazu, ale aj dôležitými prvkami v procese konštruovania moderných fixovaných typov. V príručke Training for the Theatre prikladá Saint-Denis vel'kú dôležitost' tomuto formujúcemu obdobiu svojho života, pretože sa stalo základom pre jeho d’alšiu pedagogickú prax. Rozvoj tohto prístupu ako herca-študenta prebiehal rovnakým tempom ako štandardizácia Copeauových experimentov - ústne šírených poznatkov, ktoré sa prenášali priamym kontaktom, rodili sa počas spoločných zážitkov a boli výsledkom zdiel'ania a spolupráce.

${ }^{44}$ ALDER, P. [Rischmann]. Deuxième partie: Le temps de la Compagnie des Quinze, s. 280 - 281. In Fond Michel Saint-Denis, BNF, 4-COL-83/3(2).

${ }^{45}$ J. Dasté v rozhovore s M. Saint-Denisom (1958). Pôvodný prepis dokumentu Dialogue avec Jean Dasté: l'École. Fond Michel Saint-Denis, BNF, 4-COL-83/39. Taliansky preklad M. I. Aliverti, in COPEAU, J. Artigiani di una tradizione vivente. L'attore e la pedagogia teatrale. Ed. M. I. Aliverti. Firenze : La casa Usher, 2009, s. $264-265$.

${ }^{46}$ Tamže, s. 265. 
Herecká pedagogika Saint-Denisa, ktorú divadelní historici často opomínajú, je exemplárnym príkladom z dvoch dôvodov. V prvom rade bol prvým divadelníkom, ktorý pretavil hereckú prax objavenú v École du Vieux-Colombier a aplikovanú v súbore Copiaus do zafixovanej metódy. V druhom rade bol vedúcou osobnostou, ktorá preniesla Copeauove poznatky do anglofónneho divadelného sveta. Prvou inštitúciou, ktorú Saint-Denis na tento účel založil v roku 1935, bolo London Theatre Studio. Aktívne fungovalo až do začiatku 2. svetovej vojny a stalo sa prototypom jeho pedagogickej metodológie. Londýnske štúdio reprezentuje prechod od výhradne experimentálnej praxe, t.j. výskumu, ktorý realizoval Copeau so svojimi študentmi, k etablovanej divadelnej metodike. Tento systém bol vytvorený tak, aby sa dal štandardne aplikovat’ v akýchkol'vek podmienkach. Saint-Denis sa stal správcom Copeauovho odkazu zodpovedným za transformáciu rôznych experimentálnych dielní do štruktúrovanej metódy, ako aj za d’alší rozvoj hereckých študijných programov. Po prestahovaní z Francúzska do Anglicka sa Saint-Denisovi navyše podarilo naštepit britské divadelné prostredie a stat sa spojivom medzi dvoma odlišnými divadelnými kultúrami.

Preklad z anglického jazyka: Ivan Lacko

\section{JACQUES COPEAU'S INFLUENCE IN MICHEL SAINT-DENIS' ACTOR TRAINING. FROM THE ÉCOLE DU VIEUX-COLOMBIER TO THE COMPAGNIE DES QUINZE}

\section{Cecilia CARPONI}

The transmission of actor training is a complex topic within theatre studies. Michel Saint-Denis' actor pedagogy, often neglected by theatre historians, is an exemplary case study for two main reasons. Firstly, he (Jacques Copeau's nephew, student and heirs) was the first to translate the acting practices rediscovered in the École du Vieux-Colombier and by the Copiaus group into a fixed method. Secondly, he led and adapted Copeau's teachings in the anglophone theatrical world. This study explores the first institutional context created by Saint-Denis that also constitutes the prototype of his pedagogy: the London Theatre Studio, founded in 1935 and active until the outbreak of World War II. The study investigates the transition from an entirely experimental practice - that is, the research undertaken by Copeau with his pupils - to an established method. This system was conceived for transmission, and therefore standardised. Saint-Denis appears to be the custodian of Copeau's legacy, responsible for translating a combination of experimental workshops into a structured method and for their further development in acting school programmes. Furthermore, upon his relocation from France to England, Saint-Denis contaminates the British theatrical milieu, becoming the link between two different theatre cultures.

Štúdia je príspevkom k projektu APVV č. 15-0764 Slovenské divadlo a súčasná európska divadelná kultúra - kontinuita a diskontinuita. 


\section{LITERATÚRA}

ALDER, Pierre. [Pierre Rischmann]. Deuxième partie: Le temps de la Compagnie des Quinze, s. 280 - 281. In Fond Michel Saint-Denis, BNF, 4-COL-83/3(2).

Autobiographie de Michel Saint-Denis, 1905 - 1929. In Fond Michel Saint-Denis, BNF, 4-COL$83 / 1(2)$

BALDWIN, Jane. Michel Saint-Denis and the Shaping of Modern Actor. Westport : Praeger, 2003. 240 s. ISBN 978-0313305665.

BING, Suzanne. Le journal de bord des Copiaus 1924 - 1929. Ed. Denis Gontard. Paris : Editions Segher, 1974. $224 \mathrm{~s}$.

COPEAU, Jacques. Artigiani di una tradizione vivente. L'attore e la pedagogia teatrale. Ed. Maria Ines Aliverti. Firenze : La casa Usher, 2009. 283 s. EAN 9788895065366.

DI PALMA Guido. La nozione esatta di quella porzione di fallimento che c'è in ogni opera. In Biblioteca Teatrale, 2012, BT 104.

GAUTIER, Marie-Madeleine. École du Vieux-Colombier. Notes de cours prises par Marie-Madeleine Gautier. In Fond Michel Saint-Denis, BNF, 4-COL-83/291.

GOURMEL, Jean-Baptiste. Michel Saint-Denis. Un homme de Théâtre (1897 - 1971) [dizertačná práca]. Paris : Université Paris I Panthéon Sorbonne, 2005.

List Jeana Dastého Michelovi Saint-Denisovi, (1926?). In Fond Michel Saint-Denis, BNF, 4-COL$83 / 161$.

MISTRÍK, Miloš (ed.). Jacques Copeau hier et aujourd'hui, Bratislava - Paríž : VEDA - Les Éditions de l'Amandier, 2014. 400 s. EAN 9788022414067.

SAINT-DENIS, M. Actes de la Société d'exploitation théâtrale. In Fond Michel Saint-Denis, BNF, 4-COL-83/371.

SAINT-DENIS, M. Formation du jeune acteur. In Le Théâtre dans le monde, 1954, roč. 4, č. 1, s. 37 -49 .

SAINT-DENIS, M. Histoire de Knie. In Fond Michel Saint-Denis, BNF, 4-COL-83/17.

SAINT-DENIS, M. Mes années au Vieux Colombier. In Europe: revue littéraire mensuelle, 1962, č. 396 - 397, apríl - máj, s. 62 - 70.

SAINT-DENIS, M. Prologue de Meursault. In Fond Michel Saint-Denis, BNF, 4-COLL-83/601.

SAINT-DENIS, M. Textes des prologues. In Fond Michel Saint-Denis, BNF, 4-COL-83/601.

SAINT-DENIS, M. The Theatrical contribution of Jacques Copeau. Neformálna prezentácia Michela Saint-Denisa na Divadelnom seminári, jar 1959. Fond Michel Saint-Denis, BNF, 4-COL$83 / 41$.

SAINT-DENIS, M. Theatre: the Rediscovery of Style, New York : Theatre Arts Books, 1960. 2. vydanie: Theatre: the Rediscovery of Style and other Writings. Ed. J. Baldwin. New York : Routledge Theatre Classics, 2009. 208 s. ISBN 978-0415450478.

SAINT-DENIS, M. Training for the Theatre. Premises E Promises. Ed. Suria Magito. New York - London: Theatre Arts Books-Heinemann Educational Books LTD., 1982. 243 s. ISBN 9780878305766.

VINCENT, V. „Les Jeunes Gens et l'Araignée“ ou „La Tragédie imaginaire“. In Comœdia, 12. 5. 1929.

Cecilia Carponi

Sapienza - Università di Roma

Via dei Marucciai 8

00185 Roma

e-mail: cecilia.carponi@uncoma1.it 